$10-1-2003$

\title{
Race-Conscious Affirmative Action by Tax Exempt 501(c)(3) Corporations after Grutter and Gratz
}

David A. Brennen

University of Georgia School of Law, brennend@uga.edu

p bepress

\section{Repository Citation}

David A. Brennen, Race-Conscious Affirmative Action by Tax Exempt 501(c)(3) Corporations after Grutter and Gratz (2003),

Available at: https://digitalcommons.law.uga.edu/fac_artchop/439

This Article is brought to you for free and open access by the Faculty Scholarship at Digital Commons @ University of Georgia School of Law. It has been accepted for inclusion in Scholarly Works by an authorized administrator of Digital Commons @ University of Georgia School of Law. Please share how you have benefited from this access For more information, please contact tstriepe@uga.edu. 


\title{
RACE-CONSCIOUS AFFIRMATIVE ACTION BY TAX-EXEMPT 501(C)(3) CORPORATIONS AFTER GRUTTER AND GRATZ
}

\author{
DAVID A. BRENNEN ${ }^{\dagger}$
}

\section{INTRODUCTION}

The Equal Protection Clause of the Fourteenth Amendment generally acts as a legal limit on the permissible bounds of government action. ${ }^{1}$ Accordingly, public universities and other government entities are constitutionally prohibited from engaging in acts that violate equal protection of the laws. ${ }^{2}$ The Supreme Court recently reinforced this point when it ruled, in two related cases, that public universities may consider the race of applicants when making admissions decisions, so long as an applicant's race does not amount to a deciding factor when granting admission. ${ }^{3}$ By its very terms, the constitutional

$\dagger$ Professor of Law, Mercer University School of Law; B.B.A, Florida Atlantic University; J.D., L.L.M., University of Florida College of Law. This Article is based on a presentation on April 4, 2003, at the St. John's University School of Law Symposium entitled "Intersection of Race, Corporate Law, and Economic Development." I would like to thank Leonard Baynes for organizing the Symposium. I would also like to thank my fellow panelists for their valuable insights, including Larry Cata Backer, Lisa Fairfax, Thomas Joo, Angel R. Oquendo, Steven Ramirez, Cheryl Wade, and David Troutt. As always, thanks to my wife, Kimberly Brennen, for her lasting support. Research for this Article was funded in part by a summer research grant awarded by Mercer University School of Law.

1 The Equal Protection Clause of the Fourteenth Amendment provides that "[n]o State shall ... deny to any person within its jurisdiction the equal protection of the laws." U.S. CONST. amend. XIV., § 1. See generally The Slaughter-House Cases, 83 U.S. (16 Wall.) 36 (1872) (first case to analyze the Fourteenth Amendment).

2 See Ex parte Virginia, 100 U.S. 339, 344-46 (1879) ("The prohibitions of the Fourteenth Amendment are directed to the States, and they are to a degree restrictions of State power.").

3 See Grutter v. Bollinger, 123 S. Ct. 2325, 2347 (2003) (upholding the University of Michigan Law School's affirmative action plan as consistent with the equal protection clause); Gratz v. Bollinger, 123 S. Ct. 2411, 2430 (2003) (invalidating the University of Michigan's undergraduate admissions policy as violative of the Equal Protection Clause). 
limitation imposed by the Equal Protection Clause only directly applies to government entities, not private ones. ${ }^{4}$ Private entities, however, are subject to other legal limits on the use of race as a factor that are not themselves constitutional limits but approximate to them. ${ }^{5}$ One of these pseudo-constitutional legal limits for private actors-at least those that are tax-exempt pursuant to section 501(c)(3) of the Internal Revenue Code-is the tax law's public policy limitation. ${ }^{6}$ Hence, the Supreme Court has ruled that a private university that discriminates against black people is not entitled to section 501(c)(3) taxexempt status. ${ }^{7}$ This Article examines the impact of the Supreme Court's recent decisions concerning the permissible use of race by public universities on the scope of the public policy prohibition against racial preferences by private tax-exempt entities. $^{8}$

The ultimate concern here is the continued permissibility of race-based affirmative action, in a very broad sense, in the taxexempt arena. Prior to the Supreme Court's clarification that governmental use of race is permissible for racial diversity purposes, federal courts were divided as to whether race could be justified on any basis other than remedying specific acts of prior discrimination. In light of this split in authority, the Internal Revenue Service (IRS) indicated that it could take the position,

4 See Grutter, 123 S. Ct. at 2337 (stating that states cannot discriminate based on race under the Equal Protection Clause); Gratz, 123 S. Ct. at 2427 (same).

5 See, e.g., 42 U.S.C. $\& 1971$ (1994) (stating that race, color, or previous condition not permitted to affect right to vote); 42 U.S.C. $\$ \S 2000 \mathrm{c}, 2000 \mathrm{c}-6,2000 \mathrm{~d}$ (providing that members of class of similarly situated persons are entitled to equal protection of laws and may not be denied admission to or prohibited from continuing attendance at public college by reason of race, color, religion, sex, or national origin; prohibition against exclusion from participation in, denial of benefits of, and discrimination under federally assisted programs on ground of race, color, or national origin); 42 U.S.C. $\S 3601$ (providing fair housing within constitutional limitations).

6 See Bob Jones Univ. v. United States, 461 U.S. 574, 586 (1983) ("Such an examination reveals unmistakable evidence that, underlying all relevant parts of the Code, is the intent that entitlement to tax exemption depends on meeting certain common-law standards of charity-namely, that an institution seeking taxexempt status must serve a public purpose and not be contrary to established public policy.").

7 See id. at 605.

8 For additional discussion, see generally David A. Brennen, Charities and the Constitution: Evaluating the Role of Constitutional Principles in Determining the Scope of Tax Law's Public Policy Limitation for Charities, 5 FLA. TAX REV. 779 (2002) [hereinafter Charities and the Constitution]. 
based on the direction of constitutional law, that race-based affirmative action violates established public policy. Such a position would effectively prohibit affirmative action by all section 501(c)(3) tax-exempt institutions, which includes many schools, hospitals, and other charitable entities. Thus, it is important to resolve the impact of the Supreme Court's recent decisions on private tax-exempt institutions that adopt affirmative action policies aimed at benefiting blacks, Latinas and Latinos, Native Americans, and other minorities. ${ }^{9}$ Although the Supreme Court has outlined the types of race-based affirmative action policies that may be used by public universities when making admissions decisions, it remains to be seen what impact the Court's decisions will have with respect to private entities that have obtained or desire section 501(c)(3) tax-exempt status.

Part I of this Article examines how the Equal Protection Clause limits the government's ability to engage in race-based affirmative action. Part I focuses on how constitutional law analysis has evolved in light of the Supreme Court's recent decisions in Grutter v. Bollinger and Gratz v. Bollinger. Part II provides a brief description of tax law's public policy limitation. This part shows how the IRS, though not required to do so, has generally followed Equal Protection Clause jurisprudence when applying the public policy limitation to race-based activity by private tax exempt 501(c)(3) institutions. Part III discusses how the Supreme Court's decisions in Grutter and Gratz will likely impact the way in which the IRS interprets the public policy limitation as a factor in determining the permissibility of racebased affirmative action by tax exempt 501(c)(3) institutions. Finally, this Article concludes that despite a contrary rule with respect to public institutions, private 501(c)(3) tax exempt institutions are not necessarily prohibited from using race as a deciding factor when making important decisions about matters such as admission to a private university.

9 Disputes may also arise in other contexts, as when private tax-exempt schools require applicants to prove a particular lineage, for example, Native Hawaiian, before admitting an otherwise qualified applicant. See, e.g., Adam Liptak, Student Sues for Admission to Schools for Hawaiians, N.Y. TIMES, June 29, 2003, at A18. 
I. EQUal PRotection ClaUse Limits on the Use of RaCE BY PUBLIC ENTITIES: GRUTTER AND GRATZ

On June 23, 2003, the Supreme Court decided two cases that directly impact how public universities may consider the race of an applicant for admission. In Grutter v. Bollinger, the Court upheld the University of Michigan Law School's affirmative action plan for admitting racial minorities as consistent with the Equal Protection Clause. ${ }^{10}$ In Gratz v. Bollinger, the Court struck down the University of Michigan's undergraduate minority admissions program as violative of the Equal Protection Clause. ${ }^{11}$ Both the law school and undergraduate admissions programs at issue in these cases, albeit in different ways, considered the race of each applicant. The law school program used race as one of many factors in the admission process, while the undergraduate school used race as a deciding factor in many cases. Both of these Supreme Court decisions will be pivotal in the realm of constitutional jurisprudence because they outline the parameters of appropriate race-based affirmative action by public universities and other government actors. Specifically, the Court in Grutter and Gratz finally answered a question that has divided federal courts of appeals for many years: May the government ever use race as a factor when making important decisions about matters like admission to state colleges and universities? The Supreme Court's answer to this question is yes, but only under certain conditions.

\section{A. Equal Protection Analysis Before Grutter and Gratz}

Prior to the Court's decisions in Grutter and Gratz, federal courts were split over the proper role race could play in government affirmative action plans. As the following analysis indicates, those courts that rejected the use of race in public university admissions did so because either the asserted rationale for using race or the manner in which race was used did not comply with strict scrutiny. Thus, these courts resoundingly rejected Justice Powell's assertion in his concurring opinion in Regents of University of California v. Bakke that racial diversity is a compelling government interest which may justify

10 Grutter v. Bollinger, 123 S. Ct. 2325, 2347 (2003).

11 Gratz v. Bollinger, 123 S. Ct. 2411, 2427 (2003). 
the use of race. ${ }^{12}$ On the other hand, those courts that accepted the use of race embraced Justice Powell's view of the compelling nature of racial diversity in education and concluded that racial diversity is sufficiently compelling to satisfy the Equal Protection Clause. They also recognized necessarily that remedying prior acts of specific discrimination is not the only compelling government interest for Equal Protection Clause strict scrutiny purposes.

\section{Circuits that Rejected the Use of Race}

The Courts of Appeals for the Fifth and Eleventh Circuits, prior to the Supreme Court's decisions in Grutter and Gratz, both rejected the idea that racial diversity is a compelling interest that justifies the use of race in public university admissions, albeit in different ways. The Fifth Circuit's rejection of racial diversity in Hopwood v. Texas was explicit and played a major part of the ultimate Court holding; however, the Eleventh Circuit's rejection of racial diversity was less explicit. Although the Eleventh Circuit appeared to make clear in Johnson that it agreed with the Fifth Circuit's conclusion in Hopwood that racial diversity is not a compelling government interest, the discussion was technically dicta as it was unnecessary for the court's holding. ${ }^{13}$

In Hopwood, the Fifth Circuit held that it was a violation of the Equal Protection Clause for a state to use race as a factor when making admission decisions at public university law schools. ${ }^{14}$ Hopwood involved the Fifth Circuit's review of the University of Texas Law School's admission process in which the race of applicants was considered at various stages of the application process in order to attain a diverse student body. First, racial minority applicants needed lower grade point average/Law School Admissions Test index scores than white applicants in order to gain admission. ${ }^{15}$ Second, racial minority applicants received more extensive file reviews than white

12 Regents of Univ. of Cal. v. Bakke, 438 U.S. 265, 314-15 (1978) (Powell, J., concurring).

13 Johnson v. Bd. of Regents, 263 F.3d 1234, 1249-50 (11th Cir. 2001).

14 Hopwood v. Texas, 78 F.3d 932, 962 (5th Cir. 1996). Similarly, the Fourth Circuit, in Podberesky v. Kirwan, 38 F.3d 147, 161-62 (4th Cir. 1994), held that a race-exclusive scholarship program offered by a state university violated the Equal Protection Clause of Fourteenth Amendment.

15 Hopwood, 78 F.3d at 936. 
applicants, which increased minority applicants' likelihood of admission. ${ }^{16}$ Finally, the law school maintained separate waiting lists for racial minority applicants and white applicants, again increasing the minority applicants' likelihood of admission. ${ }^{17}$ Four white applicants who were denied admission to the University of Texas Law School sued the State of Texas, claiming that the admissions process violated their rights under the Equal Protection Clause of the Fourteenth Amendment. Specifically, they claimed that the law school unconstitutionally discriminated against them based solely on their race. ${ }^{18}$

The Fifth Circuit in Hopwood $v$. Texas agreed with the rejected white applicants and reversed the district court's approval of the University of Texas Law School's admission process. ${ }^{19}$ Applying strict scrutiny, the Court explained that the state law school's interests in attaining a diverse student body and remedying effects of societal discrimination were not compelling state interests for Equal Protection Clause purposes. ${ }^{20}$ The Fifth Circuit refused to adopt Justice Powell's opinion in Bakke as binding precedent that diversity is a compelling state interest that justifies racial classifications. ${ }^{21}$ Likewise, the Fifth Circuit did not agree with the law school that its attempt to remedy the lingering effects of past discrimination by Texas's primary and secondary schools was compelling. ${ }^{22}$ Instead, the Fifth Circuit noted that the only compelling interest that would justify the state law school's use of race would be "remedying past wrongs" by the University of Texas Law School. ${ }^{23}$ Since the Fifth Circuit concluded that the law school had not crafted its admission process for this purpose, the court

16 Id. at 937.

17 Id. at 938.

18 Id.

19 Id. at 934.

20 Id. at $944-46$.

21 See id. at 945-45. The Fifth Circuit explained:

Within the general principles of the Fourteenth Amendment, the use of race in admissions for diversity in higher education contradicts, rather than furthers, the aims of equal protection. Diversity fosters, rather than minimizes, the use of race. It treats minorities as a group, rather than as individuals. It may further remedial purposes but, just as likely, may

Id. promote improper racial stereotypes, thus fueling racial hostility.

22 Id. at 948-55.

23 See id. at 945. 
held that the admission process violated the white applicants' right to equal protection.

Like the Fifth Circuit, the Eleventh Circuit in Johnson $v$. Board of Regents held that the University of Georgia's use of race in its admission process violated Equal Protection Clause standards. ${ }^{24}$ Although the University of Georgia's admission process differed in some ways from that of the University of Texas, the two processes were similar in that they both gave minority applicants an advantage over white applicants. The University of Georgia's admissions process also had three stages. At the first stage, grades, test scores, and an index score which was based on grades and test scores were considered independent of race. ${ }^{25}$ The public university automatically admitted those students with a combination of grades and test scores above a certain number. Applicants that failed to meet the qualifications for automatic admission at the first stage were moved into the second stage. At the second stage, applicants with test scores below a certain level were automatically rejected. ${ }^{26}$ For the remaining applicants at this second stage, various factors were then used to calculate a socalled TSI sccre for each applicant. ${ }^{27}$ Among the factors used to calculate the TSI score included the race of an applicant. Applicants with TSI scores below a certain level were automatically rejected, while those above a certain level were automatically admitted. Those applicants whose TSI score fell between these two levels moved to a third stage in the admissions process which did not explicitly require the consideration of the applicant's race. ${ }^{28}$

Three rejected white applicants sued the University of Georgia, claiming that the public university's admission process unconstitutionally denied them equal protection based solely on their race. ${ }^{29}$ The University of Georgia responded that considering race was necessary in order to achieve the compelling government interest of racial diversity in the classroom. ${ }^{30}$ Notably, the University of Georgia, unlike the

\footnotetext{
24 Johnson v. Bd. of Regents, 263 F.3d 1234, 1237 (11th Cir. 2001).

25 Id. at 1240.

26 Id.

27 Id.

28 Id. at 1240-41.

29 Id. at 1237.

$30 \mathrm{Id}$.
} 
University of Texas, did not allege remedying past discrimination as a justification for its consideration of race. Additionally, even though it applied strict scrutiny, the Eleventh Circuit in Johnson refused to officially rule on the university's claim that educational diversity was a compelling state interest. ${ }^{31}$ The court in Johnson refused to adopt Justice Powell's position in Bakke that racial diversity is a compelling government interest, but rather left the issue open for the Supreme Court to resolve. ${ }^{32}$ Instead, the court in Johnson concluded that even if racial diversity was a compelling interest, the university's means of obtaining that diversity-by using a "rigid, mechanical approach to considering race" of applicantswas not "narrowly tailored." 33 The Court in Johnson also concluded that the university's failure to allow for consideration of a variety of non-race factors in its admissions process or to consider any race-neutral alternatives contributed to the narrow tailoring deficiency. ${ }^{34}$

\section{Circuits That Accepted the Use of Race}

In contrast to the position taken by the Fifth and Eleventh Circuits, other courts of appeals held that racial diversity was a compelling government interest justifying the use of race by public universities in admission processes. For example, in Smith $v$. University of Washington, the Court of Appeals for the Ninth Circuit described the Fifth Circuit's opinion in Hopwood as "flawed" to the extent that it refused to recognize the compelling nature of racial diversity. ${ }^{35}$ Smith involved the Ninth Circuit's review of the University of Washington's affirmative action admission policy that took into account the race of applicants as a factor in the decision-making process. ${ }^{36}$ Smith was one of several white applicants who challenged the University of Washington's policy as violative of the Equal Protection Clause. The district court in Smith denied the plaintiffs' summary judgment motion, which alleged that race

31 Id.

32 Id. at $1244-45$.

33 Id. at $1254-55$.

34 Id. at 1254.

35 Smith v. Univ. of Washington, 233 F.3d 1188, 1200 n.9 (9th Cir. 2000) (citation omitted), cert. denied, 532 U.S. 1051 (2001).

36 Id. at 1191 . 
could not be used as a factor in public school admission decisions, ${ }^{37}$ and the Ninth Circuit affirmed the denial of summary judgment to the white plaintiffs. The Ninth Circuit in Smith explained that Justice Powell's opinion in Bakke clearly contemplated that a state school could have a compelling interest in student body diversity that would justify the use of race as an admission factor. ${ }^{38}$ In a direct reference to the Fifth Circuit's conclusion to the contrary in Hopwood, the Ninth Circuit explained: "We acknowledge that Hopwood v. Texas decided to the contrary. The flaws in that decision, however, stem from its failure to properly apply the teachings of Marks [ $v$. United States]."39

This split in authority that existed prior to the Supreme Court's decisions in Grutter and Gratz demonstrated that while it was clear that government invidious discrimination against racial minorities always violated Equal Protection, it was unclear whether benign race-based affirmative action necessarily violated Equal Protection. One author explained the split as follows:

Circuit courts uniformly interpret Bakke to hold that strict scrutiny applies to both invidious discrimination and benign affirmative action for racial minorities. Accordingly, both types of racial preferences will be upheld if the government can show that the preference is necessary to accomplish a compelling interest. This standard effectively means that any racial preference by government in favor of members of a racial majority that disadvantage members of a racial minority necessarily violates the Equal Protection Clause. Indeed, no modern day federal court has ever concluded that it was necessary to discriminate against racial minorities in order to accomplish a compelling government interest. On the other hand, Equal Protection Clause strict scrutiny does not mean that racial preferences in favor of racial minorities that disadvantage racial majorities necessarily violate the Equal Protection Clause. The Fifth Circuit's view is that it is never necessary to favor a racial minority over a racial majority in order to accomplish a compelling government interest. [Other] [c]ircuits' views are that it may be necessary to make such racial preferences in order to accomplish compelling

\footnotetext{
37 Id.

38 See id. at 1197.

39 Id. at 1200 n.9; see also Marks v. United States, 430 U.S. 188, 193 (1977).
} 
government interests. This aspect of Equal Protection Clause strict scrutiny is the central reason why Federal Circuit Courts are divided on the issue of whether race may ever be a factor in government affirmative action efforts. ${ }^{40}$

Thus, prior to Grutter and Gratz, it was one's geographic location-either in the Fifth Circuit or in the Ninth Circuit-that determined whether race could be used as a factor in government decision making. For states not located within one of the circuits where the issue had been addressed, it was uncertain what the proper rule was. Prior to Grutter and Gratz, the answer was unclear for most of the country's public entities. Thus, Equal Protection Clause constitutional law analysis was in somewhat of a state of flux with regard to whether a government could ever rely on race as a factor in making important decisions until the Supreme Court decided Grutter and Gratz.

\section{B. The Impact of Grutter and Gratz on Equal Protection Analysis}

The Supreme Court's decisions in Grutter v. Bollinger ${ }^{41}$ and Gratz v. Bollinger ${ }^{42}$ on Equal Protection constitutional analysis are clear: race may be used as a factor by government decision makers. Granted, the Court's decisions in these cases do not permit the government's unbridled use of race in its decisionmaking process. Indeed, the Court's differing conclusions with respect to the law school case and the undergraduate case make this point abundantly clear. The fact remains, however, that, after these decisions, race is not necessarily discounted as an inappropriate factor to consider in public university admissions.

\section{The Law School Case: Grutter v. Bollinger}

In Grutter v. Bollinger, the Supreme Court considered whether the University of Michigan Law School's admission policy, which explicitly considered the race of the applicant along with other factors, violated the Equal Protection Clause of the Fourteenth Amendment. ${ }^{43}$ The express purpose for this elite public law school considering race was to achieve a racially

\footnotetext{
40 Charities and the Constitution, supra note 8, at 822.

41 Grutter v. Bollinger, 123 S. Ct. 2325 (2003).

42 Gratz v. Bollinger, 123 S. Ct. 2411 (2003).

43 Grutter, 123 S. Ct. at 2331-32.
} 
diverse student body. ${ }^{44}$ The law school's policy, however, did not use race as a deciding factor of admission. Instead, race, along with other factors such as grades, test scores, and background, was used in a flexible manner to judge the ability of the applicant to contribute meaningfully to life at the law school. ${ }^{45}$ The thought was that such diversity would contribute significantly to the educational experience of all law students. ${ }^{46}$ Thus, because of the admission policy, grades and test scores alone did not determine admission. Indeed, just as "the highest possible score [did] not guarantee admission [under the policy]," a low score did not "automatically disqualify an applicant" either. ${ }^{47}$

A white applicant, whose application for admission was denied, challenged the law school's admission policy in federal court claiming that as a result of the race-based admission policy, the law school violated her right to equal protection..$^{48}$ The district court, determining that the law school's interest in student body diversity was not a compelling governmental interest and that its use of race was not narrowly tailored to achieve diversity, concluded that "the [1]aw [s]chool's use of race as a factor in admissions decisions was unlawful." 49 The Court of Appeals for the Sixth Circuit reversed, holding "that Justice Powell's opinion in Bakke was binding precedent establishing diversity as a compelling state interest" and that the law school's use of race was narrowly tailored because race was merely a "potential 'plus' factor" and not a deciding factor of admission..$^{50}$ The Supreme Court, citing Hopwood v. Texas and Smith v. University of Washington, agreed to hear the Grutter case so as to finally resolve the issue of "[w]hether diversity is a compelling interest that can justify the narrowly tailored use of race in selecting applicants for admission to public universities." ${ }^{51}$

At the outset of the opinion, Justice O'Connor, writing for the majority, expressly adopted Justice Powell's view of racial diversity as expressed in his concurring opinion in Bakke.

\footnotetext{
44 Id. at 2332.

45 Id.

46 Id.

47 Id.

48 Id.

49 Id. at 2335.

$50 I d$.

51 Id.
} 
Justice O'Connor explained: “[W]e endorse Justice Powell's view that student body diversity is a compelling state interest that can justify the use of race in university admissions." ${ }^{52}$ Thus, the remainder of the majority opinion was devoted to an examination of whether the University of Michigan Law School's plan actually complied with strict scrutiny under Equal Protection Clause. On the question of racial diversity as the law school's actual objective, the Court in Grutter explained that it essentially deferred to the school's judgment as to how essential racial diversity is to its educational mission. ${ }^{53}$ The Court noted that the law school's objectives of achieving a "critical mass" of minority students as opposed to a prescribed number or percentage, preparing students for a diverse workforce, and educating a more diverse group of potential leaders were all strong indicators of the school's educational purposes. ${ }^{54}$

The Court in Grutter also concluded that the law school's admission policy was narrowly tailored because it used race "in a flexible, nonmechanical way" and did not "insulate applicants who belong[ed] to certain racial or ethnic groups from the competition for admission." ${ }^{55}$ Indeed, the law school's admission program did not amount to a quota system for minorities. Instead, the law school's plan "permit[ted] consideration of race as a 'plus' factor in any given case while still ensuring that each candidate 'compete[d] with all other qualified applicants.' "56 The Court recognized that the law school's admissions process was "highly individualized" and involved a "holistic review of each applicant's file giving serious consideration to all the ways an applicant might contribute to a diverse educational environment." 57 Importantly, the Court determined that the law school did not have a policy of automatic acceptance or rejection based on race or any other factor for that matter. ${ }^{58}$ The Court also refused to hold that narrow tailoring required the use of any available non-race alternatives, such as adopting a race-neutral lottery-type system or de-emphasizing grades. ${ }^{59}$ Instead, the law

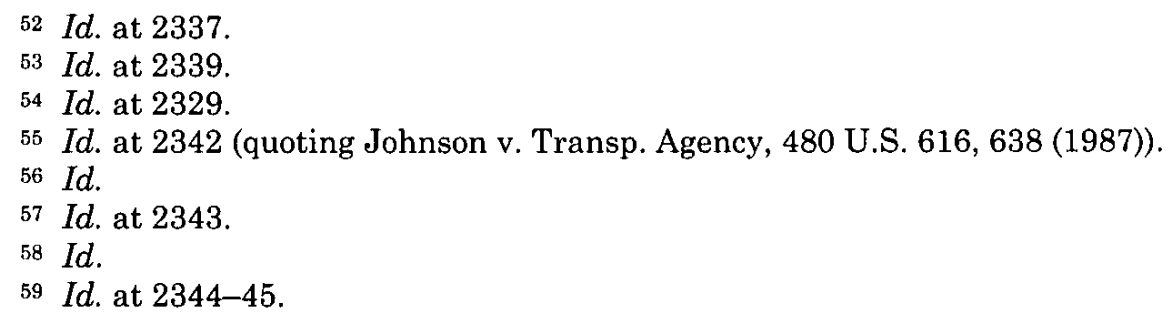


school's refusal to adopt such alternatives to considering race did not diminish its compliance with the narrow tailoring aspect of strict scrutiny if those alternatives would require a dramatic drop in "the academic quality of all admitted students." 60

\section{The Undergraduate Case: Gratz v. Bollinger}

On the same day that the Supreme Court decided Grutter, it also decided Gratz $v$. Bollinger, a case involving the constitutionality of the University of Michigan's undergraduate admission policy. ${ }^{61}$ Like the law school policy, the undergraduate policy also used race as a factor in making admission decisions; however, unlike the law school's admission policy the undergraduate policy used race as a deciding factor, a practice that the Supreme Court rejected as inconsistent with Equal Protection. ${ }^{62}$

In Gratz, two white applicants who were denied admission into one of the University of Michigan's undergraduate colleges sued the university claiming that their denial of admission violated their constitutional rights to equal protection. ${ }^{63}$ The undergraduate admission policy in Gratz required admissions counselors to use university-wide, written guidelines in making admission decisions that would "promote consistency in the review of the large number of applications received."64 The guidelines identified a number of factors counselors were required to use in making admission decisions, which included grades, test scores, school quality, curriculum strength, geography, alumni relationships, leadership, and race. ${ }^{65}$ Upon compiling these factors, admission counselors would convert the factors for each applicant into a special "GPA 2" score. ${ }^{66}$ The counselors would then use guideline tables containing predetermined combinations of "GPA 2" scores and ACT/SAT scores to decide whether to admit, reject, delay, or postpone an applicant. ${ }^{67}$ Different combinations of scores were used to make

\footnotetext{
60 Id. at 2345.

61123 S. Ct. 2411, 2417 (2003).

62 Id. at $2428,2430$.

63 Id. at 2417-18.

64 Id. at 2418.

65 Id. at 2418-19.

66 Id. at 2419.

67 Id.
} 
admissions decisions based on the race of the applicant. ${ }^{68}$ Both white plaintiffs challenging the policy had score combinations which rendered their applications postponed; whereas minority applicants with the same score combinations would generally have been automatically admitted. ${ }^{69}$ The undergraduate university later revised its admission policy by instituting a selection index "under which every applicant from an underrepresented racial or ethnic minority group was awarded 20 points," which was one-fifth of the points needed to gain automatic admission. ${ }^{70}$

The university, again relying on Justice Powell's concurring opinion in Bakke, defended its use of race on the ground that it was necessary to consider race in order to attain a diverse undergraduate student body. ${ }^{71}$ Though the Court agreed that racial diversity could justify the use of race in some cases, it concluded that the University of Michigan's use of race in its undergraduate admissions was not narrowly tailored to achieve the interest asserted. ${ }^{72}$ The Court explained that the undergraduate policy did not provide the "individualized consideration" required for strict scrutiny because it "automatically distribute[d] 20 points to every single [minority] applicant" solely because of the applicant's race. ${ }^{73}$ Further, whereas Justice Powell's conception of an appropriate affirmative action plan required that race not be a decisive factor, the undergraduate policy "ha[d] the effect of making "the factor of race ... decisive" " for minority applicants. ${ }^{74}$ The Court in Gratz rejected the university's attempt to ameliorate the decisive impact of race by flagging certain applications for individualized review by a special admissions committee because "such consideration [was] the exception and not the rule in the operation" of the admissions program. ${ }^{75}$ Indeed, the special committee reviewed only some of the applications. The Court further rejected the university's claim that the administrative difficulty of providing individualized review for each of its

\footnotetext{
68 Id. at 2419 n.7.

69 Id. at 2419 .

70 Id. at 2420.

$71 \mathrm{Id}$.

$72 I d$. at $2427-28,2430$.

$73 \mathrm{Id}$. at 2428.

74 Id. (quoting Regents of the Univ. of Cal. v. Bakke, 438 U.S. 265, 317 (1978)).

75 Id. at 2429.
} 
applicants warranted that the school's policy withstood strict scrutiny, concluding instead that Justice Powell's opinion in Bakke did not allow for such exceptions. ${ }^{76}$

The Court's decisions in Grutter-that racial diversity justifies the flexible use of race as one of many factors of admissions-and Gratz-that racial diversity does not justify the use of race as a deciding factor of admission-are very instructive. These decisions finally clarify that government actors can use race-based affirmative action policies in order to achieve compelling government interests. Importantly, the Court has confirmed that achieving racial diversity in the classroom can be as compelling an interest as is remedying specific acts of prior discrimination. Even though the Court has sanctioned the use of race by government actors, however, it cautions that racial policies must be flexible enough such that race does not amount to a deciding factor. Thus, the Court would likely invalidate a government policy that automatically granted government benefits to a person solely because of that individual's race. Conversely, the Court would likely uphold a government policy that used race as one of many factors to assess the unique qualities of an individual. While the ongoing division among the federal courts on the issue of the permissible use of race by government actors is now resolved, a related issue still exists: What does this mean for non-government private actors who are subject to tax law's public policy limitation? Does the same demarcation between flexible use of race and using race as a deciding factor apply?

\section{TAX LAW LIMITS ON THE USE OF RACE BY PRIVATE ENTITIES: The PUBLiC Policy LiMITATION}

As discussed in Part I above, the Court has finally resolved the issue of how and when government actors may take account of race in their decisions. Government actors, however, do not have a monopoly on important societal functions; private educational institutions coexist with state universities. Many, if not most, of these private universities and schools are organized as section 501(c)(3) tax-exempt institutions under the Internal Revenue Code. Additionally, many of these private educational institutions receive direct federal funding and are therefore

76 Id. at 2430 . 
subject to federal civil rights laws. ${ }^{77}$ The Supreme Court has interpreted federal civil rights laws as essentially imposing the same restrictions on private activity as the Equal Protection Clause imposes on government activity when it comes to racial distinctions. ${ }^{78}$ It follows that even though these private recipients of federal funds are not technically government actors, they are still subject to the same restrictions imposed by the Equal Protection Clause on government institutions. ${ }^{79}$

Private non-governmental institutions often choose not to accept federal funds in order to avoid application of federal civil rights laws. For example, Bob Jones University, formerly a section 501(c)(3) tax-exempt institution, stopped accepting all direct federal funds years ago when it appeared that its racially discriminatory policies might cause it to violate federal civil rights laws. ${ }^{80}$ Later, when the Supreme Court held that Bob Jones University could not operate as a section 501(c)(3) taxexempt institution while discriminating against AfricanAmericans, Bob Jones University chose to relinquish its taxexempt status rather than change its racially discriminatory policies. ${ }^{81}$ Additionally, a private school in Hawaii that has 501(c)(3) tax-exempt status recently decided to stop accepting federal funds so that it too could avoid violation of federal civil rights laws that prohibit discrimination by recipients of federal financial assistance. ${ }^{82}$ Interestingly, two days after the Court issued its decisions in Grutter and Gratz, a student who was

77 See, e.g., 42 U.S.C. $\S 2000 d$ (2000) ("No person in the United States shall, on the ground of race, color, or national origin, be excluded from participation in, be denied the benefits of, or be subjected to discrimination under any program or activity receiving Federal financial assistance." (emphasis added)).

78 See David A. Brennen, Tax Expenditures, Social Justice and Civil Rights: Expanding the Scope of Civil Rights Laws To Apply to Private Charities, 2001 BYU L. REV. 167, 179-81 (2001) (illustrating that federal civil rights statutes, such as Title VI of the Civil Rights Act of 1964, prohibit private actors from discriminating based on race, color, or national origin).

79 See id. at 171-72, 192-93.

80 See Bob Jones Univ. v. Johnson, 396 F. Supp. 597, 600 (D. S.C. 1974), aff'd, 529 F.2d 514 (4th Cir. 1975) (stating that Bob Jones University refuses to accept any government funds or grants because it "believe[s] such acceptance would cause the surrender of its religious principles and infringe upon its right to operate in harmony with such principles").

81 See id. The Court agreed with the Internal Revenue Service that Bob Jones University's tax-exempt status should be denied because the University maintained racially discriminatory policies. Id. at 605 .

${ }_{82}$ See generally Liptak, supra note 9, at A18 (explaining how the school is funded by way of a trust created in 1884). 
denied admission by the private tax-exempt school in Hawaii sued the school, claiming that the school denied him admission solely because of his lineage in violation of federal civil rights laws. ${ }^{83}$ For private institutions that do not receive federal financial assistance and are tax-exempt via section 501(c)(3), the only legal restriction on their use of race is tax law's public policy limitation.

\section{A. Tax Law's Public Policy Limitation}

Charities are entities exempt from the federal income tax, as described in section 501(c)(3) of the Internal Revenue Code. ${ }^{84}$ The guiding principle for these special tax-exempt entities, at least when it comes to race-conscious decisions and similar concerns, is the public policy limitation as outlined by the Supreme Court in Bob Jones University $v$. United States. ${ }^{85}$ In Bob Jones University, the Supreme Court revoked the taxexempt status of a charity-in that case a private tax-exempt religious university-that discriminated against black people in making admissions decisions. ${ }^{86}$ In determining that there was a "fundamental public policy" against such discrimination, the Court in Bob Jones University analyzed decisions by various federal authorities, which had unanimously concluded that discrimination against black people in public education is unconstitutional and against public policy. ${ }^{87}$ Accordingly, the Court in Bob Jones University upheld the IRS's revocation of Bob Jones University's section 501(c)(3) tax-exempt status by proclaiming that tax-exempt charities cannot violate established public policy. 88

Since its decision in Bob Jones University, the Supreme Court has never again addressed the issue of whether particular action by a charity violates the public policy limitation. In fact, other than in the obvious case of racial discrimination against

83 See id.

84 I.R.C. $\S 501(\mathrm{c})(3)(2000)$.

85 461. U.S. 574 (1983). See also Jones et al., THE TAX LAW OF CHARITIES AND OTHER EXEMPT ORGanizations: CASES, MATERIALS, QUESTIONS AND ACTIVTTIES, 11-16 (West Publications 2003).

$86 I d$. at 605.

87 Id. at 592-96.

88 See David A. Brennen, The Power of the Treasury: Racial Discrimination, Public Policy, and "Charity" in Contemporary Society, 33 U.C. DAVIS L. REV. 389, 403 (2000). 
black people, ${ }^{89}$ the IRS has never used the public policy limitation as a basis for revoking or denying tax-exempt charitable status. However, the IRS has indicated a willingness to consider the prospect of using the public policy limitation in contexts other than racial discrimination against black people. Thus, when a charity uses racial preferences, not against black people, but in the context of a broader policy aimed at helping blacks and other minorities, the IRS has implicitly asked whether such race-conscious affirmative action violates "established public policy?"90

\section{B. Application of the Public Policy Limitation to Race-Conscious Affirmative Action Before Grutter and Gratz}

Prior to the Supreme Court's recent decisions in Grutter and Gratz, the IRS essentially concluded that race-conscious affirmative action by private, tax-exempt universities and other charities did not violate the public policy limitation. The IRS appears to have based this position on the fact that raceconscious affirmative action by government is not always unconstitutional. ${ }^{91}$ The most telling example of the IRS's position with regard to this issue is a statement made in a 1999 Technical Advice Memorandum (TAM) issued to a private, taxexempt trust, commonly referred to as the Bishop Estate. ${ }^{92}$ The trust involved in the Bishop Estate TAM operated a school that only admitted students of Hawaiian ancestry. The IRS concluded that the trust did not violate tax law's public policy limitation by denying admission to non-native Hawaiians. ${ }^{93}$ However, the TAM went on to advise the trust that it "should consider requesting a private letter ruling on whether the [then

89 See, e.g., Calhoun Acad. v. Comm'r., 94 T.C. 284, 305 (1990) ("After a comprehensive review of the administrative record, we find that petitioner has not carried its burden to show that it operates in good faith in accordance with a racially nondiscriminatory policy as to students. ... Accordingly, petitioner has not shown that [the service] was erroneous in denying petitioner tax-exempt status under section 501(c)(3)."); see also Va. Educ. Fund v. Comm'r., 85 T.C. 753, 746-47 (1985) (discussing acceptable standards of proof for a charity to show that it has not violated non-discrimination requirements).

90 See generally Charities and the Constitution, supra note 39.

91 See id; see also Tech. Adv. Mem. (issued to the Kamehameha Schools/Bernice Pauahi Bishop Estate) (unpublished) (Feb. 4, 1999) (on file with the author) [hereinafter "Bishop Estate TAM"].

92 See Bishop Estate TAM, supra note 90.

93 See id. 
pending Supreme Court] decision [in Rice v. Cayetano] would have any effect on the analysis." ${ }_{4}$ Rice concerned the constitutionality, under the Fifteenth Amendment, of Hawaii's practice of denying non-native Hawaiians the fundamental right to vote for trustees of the Office of Hawaiian Affairs. ${ }^{95}$

In suggesting that the pending Rice case was relevant to its decision on the permissibility of the trust's Hawaiians-only policy in the 1999 TAM, the IRS relied on "several Supreme Court opinions addressing the constitutional challenges to governmental actions under the Equal Protection Clauses of the Fourteenth [and] Fifth Amendment[s]."96 The Supreme Court opinions identified in the 1999 TAM and relied upon by the IRS generally recognized that race-conscious affirmative action by government was permissible as long as government had a compelling interest and the consideration of race was necessary to accomplish that interest. ${ }^{97}$ After these pre-Grutter and preGratz Supreme Court cases were decided, however, some federal circuit courts decided that race should never be considered in the context of remedial affirmative action. ${ }^{98}$ Other courts decided that it may be necessary, at times, to consider race in this context. ${ }^{99}$ Thus, in contrast to the time the Court decided Bob Jones University, when there was a uniform view that racial discrimination against black people was always unconstitutional and never appropriate, federal courts were divided prior to Grutter and Gratz as to whether considerations of race were appropriate in the context of remedial affirmative action by government.

94 See id; see also Rice v Cayetano, 528 U.S. 495 (2000).

95 See Rice, 528 U.S. 495.

96 See Bishop Estate TAM, supra note 90.

97 In regard to Regents of the University of California v. Bakke, 438 U.S. 265 (1978), and Adarand Constructors, Inc. U. Pena, 515 U.S. 200 (1995), the IRS stated that "[t]he Court in both cases, however, recognized that there would be situations in which benefits to ethnic minorities would be appropriate to further compelling governmental interests." See Bishop Estate TAM, supra note 90.

98 See, e.g., Johnson v. Bd. of Regents of Univ. of Ga., 263 F.3d 1234, 1270 (11th Cir. 2001); Hopwood v. Texas, 78 F.3d 932, 962 (5th Cir. 1996), cert. denied, 518 U.S. 1033 (1996).

99 See, e.g., Grutter v. Bollinger, 288 F.3d 732, 752 (6th Cir. 2002), cert. granted, 123 S. Ct. 2325 (2002); Smith v. Univ. of Wash., 233 F.3d 1188, 1200-01 (9th Cir. 2000), cert. denied, 532 U.S. 1051 (2001). 


\section{RACIAL PREFERENCES BY PRIVATE TAX-EXEMPT SCHOOLS IN LIGHT OF GRUTTER AND GRATZ}

One of the most salient aspects of tax law's public policy limitation is that a particular public policy must be clear and established before it can be said to be an "established public policy" that tax-exempt charities cannot violate. Prior to Grutter and Gratz, the IRS took the position that race-conscious affirmative action did not violate established public policy. Two aspects of constitutional law supported this tax law position: the split among the courts of appeals and the differences between the Court's past treatment of invidious racial discrimination and affirmative action by government.

The split among the courts of appeals on the issue of using race as a factor in government affirmative action indicated that it was highly unlikely that a court, or the IRS for that matter, would conclude that there was a clear or established public policy against race-conscious affirmative action. For example, in the Fifth Circuit, race-conscious affirmative action was absolutely prohibited by government. ${ }^{100}$ Conversely, in the Ninth Circuit, race-conscious affirmative action was permitted by government. 101 Outside of these circuits, no clear guidance existed. However, this state of affairs with respect to raceconscious affirmative action was very different than the state of affairs with respect to invidious discrimination against blacks and other minorities. Indeed, invidious racial discrimination by government has long been expressly prohibited. Thus, if tax law's public policy standard is viewed as coexistent with the constitutional law standard embodied in the Equal Protection Clause, then prior to Grutter and Gratz it was clear that invidious racial discrimination was contrary to "established public policy." However, it was not "clear" that affirmative action violated this same tax standard.

With the Court's recent decisions in Grutter and Gratz, the state of affairs with respect to race-conscious affirmative action has changed. It is now clear that race-conscious affirmative action by government actors is permissible throughout the United States. As the Supreme Court explained, race may be used by government as one factor among many when providing

100 See Hopwood, 78 F.3d at 962 .

101 See Smith, 233 F.3d at 1200-01. 
government benefits, ${ }^{102}$ as long as race is not used as the deciding factor. ${ }^{103}$ Whereas government entities in some circuits were prohibited from using race, post-Grutter and post-Gratz, no government entity in any circuit is now prohibited from properly using race as a factor. Accordingly, the IRS is on even stronger footing than before Grutter and Gratz in concluding that raceconscious affirmative action is not prohibited by tax law's public policy limitation. If the IRS continues to rely almost exclusively on constitutional jurisprudence to decide the scope of the public policy limitation, it should view the decision in Grutter as further supporting its view that race-conscious affirmative action is consistent with established public policy.

The IRS, however, is not necessarily bound to continue to rely exclusively on constitutional law as the sole determinant of what is and what is not a violation of established public policy. First, the constitutional provision at issue in Grutter, the Equal Protection Clause of the Fourteenth Amendment, applies directly to government actors, not private actors like tax-exempt charities. Thus, while state colleges and universities are directly bound to abide by the Court's constitutional decision in Grutter, private colleges and universities are not. These private institutions, however, may be indirectly affected by the Court's decision in Grutter by virtue of statutory civil rights laws that deny federal financial assistance to private entities that discriminate based on race. ${ }^{104}$ In many cases, racial preferences that violate the Constitution may also violate civil rights laws. However, the IRS has never before used violation of these civil rights laws as the sole basis for denying or revoking a charity's tax-exempt status.

Second, nothing in the Bob Jones University opinion mandates that every act that the Supreme Court declares unconstitutional also violates the public policy limitation or vice versa. Indeed, the Court in Bob Jones University did not conclude that charities must comply with the Constitution. Instead, it concluded that charities must comply with "established public policy." 105 As the Supreme Court's analysis in Bob Jones University illustrates, a determination as to whether a

102 Grutter, 123 S. Ct. at 2338.

103 Gratz v. Bollinger, 123 S. Ct. 2411, 2427-28 (2003).

104 See, e.g., Civil Rights Act of 1964, tit. VI, $\S 601,42$ U.S.C. $\$ 2000 d$ (2000).

105 Bob Jones Univ. v. United States, 461 U.S. 574, 586 (1983). 
particular act or policy violates "established public policy" includes consideration of not only constitutional permissibility but also other factors. ${ }^{106}$ Thus, a decision that forbids any consideration of race by government entities would not necessarily equate with a public policy. This means that taxexempt entities that engage in the type of race-conscious decision making undertaken by the University of Michigan in its undergraduate admissions process may not violate established public policy, even though such action would likely be unconstitutional if engaged in by government actors.

\section{CONCLUSION}

In sum, the IRS has taken the position that the Supreme Court's constitutional law decisions have a significant bearing on whether race-conscious affirmative action policies violate tax law's public policy limitation. Accordingly, Grutter and Gratz provide a clear indication that the IRS will not soon deny or revoke the tax-exempt status of charities that engage in the type of race-conscious affirmative action engaged in by the University of Michigan Law School. So long as a tax-exempt charity, a private university for example, limits its use of race to being one of many factors in making affirmative action decisions, the IRS is unlikely to challenge the action as violative of "established public policy."

The IRS, however, is not bound to continue viewing constitutional law as determinative of what is, and is not, "established public policy." Indeed, the IRS may consider factors that do not stem from constitutional jurisprudence when determining if a particular charity's race-conscious affirmative action violates the public policy limitation. Conceptually, the public policy limitation does not need to be co-extensive with the totality of constitutional jurisprudence. Thus, the IRS might properly conclude that the type of affirmative action the Court invalidated in Gratz as unconstitutional might still be consistent with established public policy if engaged in by a nongovernmental private tax-exempt actor. Based on such an approach, the IRS could determine that, even though public universities are prohibited from using race as a deciding factor of admission, private universities are not necessarily prohibited

$106 I d$. 
from using race in this way. Such an approach would be entirely consistent with Justice Powell's view of tax-exempt charities as contributing to a "vigorous, pluralistic society" and not acting "on behalf of Government in carrying out governmentally approved policies." 107

107 See id. at 609-10 (Powell, J. concurring). Justice Powell explains:

Even more troubling to me is the element of conformity that appears to inform the Court's analysis. The Court asserts that an exempt organization must "demonstrably serve and be in harmony with the public interest," must have a purpose that comports with "the common community conscience," and must not act in a manner "affirmatively at odds with [the] declared position of the whole government." Taken together, these passages suggest that the primary function of a tax-exempt organization is to act on behalf of the Government in carrying out governmentally approved policies. In my opinion, such a view of $\S$ 501(c)(3) ignores the important role played by tax exemptions in encouraging diverse, indeed often sharply conflicting, activities and viewpoints. As Justice BRENNAN has observed, private, nonprofit groups receive tax exemptions because "each group contributes to the diversity of association, viewpoint, and enterprise essential to a vigorous, pluralistic society." Far from representing an effort to reinforce any perceived "common community conscience," the provision of tax exemptions to nonprofit groups is one indispensable means of limiting the influence of governmental orthodoxy on important areas of community life. Given the importance of our tradition of pluralism, "[t]he interest in preserving an Id. area of untrammeled choice for private philanthropy is very great." 
ST. JOHN'S LAW REVIEW

HeinOnline -- 77 St. John's L. Rev. 7342003 